\title{
TRADITIONAL GAME (GAPYAK) AS EFFORT TO DEVELOP COMMUNICATION AND STUDENT COOPERATION IN 1 BUMIREJO ELEMENTARY SCHOOL
}

\author{
Ingtiarti, Nur Rofiqoh, Ivan Arifudin, Kartika Chrysti Suryandari
}

Universitas Sebelas Maret

ingtiarti@gmail.com

\section{Article History}

accepted 30/09/2018

approved 12/10/2018

published 30/10/2018

\section{Keywords}

traditional games, communication, cooperation

\begin{abstract}
Recently, traditional game among students, particularly gapyak, have begun to fade and are forgotten due to the times. Gapyak has been replaced by modern technology-based games that have a high level of addiction, resulting in changes in student behavior and habits. They tend to be less socializing with people around. As a result, students lack of communication and collaboration in daily life. This research to foster communication and collaboration of students in SD Negeri 1 Bumirejo. The research subjects were 27 grade $V$ students of SD Negeri 1 Bumirejo. The object of the research is communication and student collaboration in the game Gapyak. The research design is descriptive qualitative with data collection techniques through observation sheets and interview sheets which are then described. The results showed that the traditional game Gapyak in communicating "good" criteria with a percentage of $80 \%$, and in cooperation the criteria "good" with a percentage of $83 \%$. This can be seen from observations that show that students are able to communicate, cooperate, and responsible.
\end{abstract}

Social, Humanities, and Education Studies (SHEs): Conference Series https://jurnal.uns.ac.id/shes

p-ISSN 2620-9284

e-ISSN 2620-9292 


\section{PENDAHULUAN}

Pada era sekarang, teknologi dalam berbagai bidang mengalami kemajuan yang sangat pesat. Kemajuan yang sangat pesat dikarenakan manusia ingin hidup lebih aman, lebih baik dan keluar dari masalah yang dihadapinya. Kemajuan teknologi ini menyebabkan pergeseran budaya, terutama pada perilaku dan kebiasaan siswa. Salah satu bentuk kemajuan teknologi tersebut yaitu munculnya permainan modern seperti, video game, playstation dan games online. Permainan modern banyak digemari oleh siswa SD dan menyebabkan kecanduan yang tinggi. Akibatnya, siswa menghabiskan banyak waktu untuk bermain game online. Banyaknya waktu yang digunakan untuk bermain game online telah merubah siswa menjadi kurang bersosialisasi dan memiliki ego yang tinggi.

Siswa lebih cenderung suka bermain permainan modern karena adanya dukungan dari orangtua yang menyediakan berbagai fasilitas untuk mengakses permainan modern seperti, smartphone dan laptop. Orangtua tidak memperkenalkan permainan zaman dahulu atau tradisional yang lebih menanamkan nilai-nilai yang terkandung dalam sila-sila Pancasila.

Berdasarkan fakta diatas, peneliti melakukan penelitian yang bertujuan untuk mengidentifikasi munculnya komunikasi dan kerjasama dalam permainan tradisional. Menurut Adistyasari (2013: 54), keterampilan sosial dan kerjasama siswa merupakan hal penting yang dibutuhkan siswa untuk berinteraksi dengan teman sebaya, keluarga dan lingkungan. Tetapi pada kenyataannya, di negeri ini banyak fakta yang menunjukkan bahwa masih rendahnya kerjasama dan interaksi antar siswa atau pelajar. Rendahnya kerjasama dan interaksi atau komunikasi antar siswa ini dipengaruhi oleh perkembangan gaya hidup yang semakin individual dan perkembangan teknologi yang semakin canggih seperti banyaknya permainan berteknologi yang banyak digemari siswa karena canggih, asik dan tidak melelahkan karena hanya dimainkan dengan duduk berdiam diri sehingga membuat siswa menjadi acuh tak acuh dengan orang lain, sering mementingkan diri sendiri dan kurang bersosialisasi dengan orang-orang di sekitarnya.

Pada era globalisasi ini, manusia dihadapkan pada tuntutan akan pentingnya sumber daya manusia yang berkualitas serta mampu berkompetensi, cakap dalam berkomunikasi, dan dapat bekerjasama dengan baik. Sumber daya manusia yang berkualitas, yang dihasilkan oleh pendidikan yang berkualitas pula, yaitu dengan mengadakan permainan tradisional yang memiliki banyak nilai, dapat menjadi kekuatan utama untuk mengatasi masalah-masalah yang dihadapi dalam pendidikan, sehingga melalui adanya permainan tadisional "gapyak" diharapkan dapat menciptakan sumber daya yang benar-benar berkualitas serta mampu berkompetisi, cakap dalam berkomunikasi dan bekerjasama dengan baik.

Menurut Depdiknas (Sari I. J, Murni D, Sjaifuddin, 2016) kecakapan komunikasi dapat diketahui melalui komunikasi lisan dan tulisan siswa. Komunikasi lisan dapat mengukur kemampuan mendengarkan dan menyampaikan pesan siswa, sedangkan komunikasi tulisan hanya dapat mengukur kemampuan siswa dalam menyampaikan pesan.

Disamping komunikasi yang baik, siswa juga harus dapat bekerjasama dengan baik pula. Adapun indikator kerjasama siswa yang dapat mengukur kemampuan kerjasama siswa menurut Lungdren yaitu: (a) menggunakan kesepakatan, (b) menghargai kontribusi, (c) mengambil giliran dan berbagi tugas, (d) berada dalam kelompok, (e) berada dalam tugas, (f) mendorong partisipasi, (g) mengundang orang lain, (h) menyelesaikan tugas dalam waktunya, dan (i) meghormati perbedaan individu (Isjoni, 2012: 46-47).

Penelitian ini dilakukan pada siswa Sekolah Dasar (SD) kelas V. Dilakukannya pada siswa SD karena pada jenjang tersebut merupakan dasar untuk siswa dapat menanamkan kemampuannya dalam bersosialisasi berkomunikasi dan bekerja sama 
yang didapatnya sebelum memasuki jenjang yang lebih tinggi, dengan harapan siswa dapat lebih terbiasa untuk bekerja sama atau berinteraksi dalam kelompok dan berkomunikasi. Kelas $\mathrm{V}$ yang dipilih karena pada jenjang kelas tersebut, siswa sudah berani untuk berkomunikasi meskipun masih ada yang malu- malu dan dapat bekerjasama dalam kelompok.

Dari informasi yang didapat, maka penulis memutuskan untuk melakukan penelitian dengan judul "Traditional Game (Gapyak) As Effort To Develop Communication And Student Cooperation In 1 Bumirejo Elementary School".

\section{METODE}

Desain penelitian yang digunakan yaitu deskriptif kualitatif. Deskriptif kualitatif digunakan karena penelitian dilakukan untuk mengambil informasi langsung yang ada di lapangan tentang deskripsi kemampuan komunikasi dan kerjasama siswa di kelas $\mathrm{V}$ dalam permainan tradisional gapyak.

Penelitian ini dilaksanakan tanggal 7 September 2018 sampai tanggal 16 September 2018 di SD Negeri 1 Bumirejo. Subjek dalam penelitian ini adalah siswa kelas V SD Negeri 1 Bumirejo tahun ajaran 2018/2019, yang terdiri dari 27 siswa. Data penelitian ini berupa data kualitatif yaitu berupa kemampuan komunikasi dan kerjasama siswa dilihat berdasarkan kriteria sangat baik, baik, cukup, kurang baik dan sangat kurang baik. Data penelitian diambil menggunakan 2 teknik pengumpulan data yaitu observasi dan wawancara. Teknik analisis data yang digunakan dalam penelitian ini adalah analisis deskriptif dimana data dan informasi yang diperoleh dari lapangan dideskripsikan secara kualitatif. Pada penelitian ini untuk mengamati kemampuan komunikasi dan kerjasama siswa menggunakan lembar observasi. Lembar observasi ini digunakan peneliti untuk melihat kemampuan komunikasi dan kerjasama yang terjadi pada saat dilaksanakan permainan tradisional gapyak dengan kriteria-kriteria mengenai kemampuan komunikasi dan kerjasama. Untuk mendeskripsikan kemunculan komunikasi dan kerjasama pada permainan tradisional gapyak menggunakan pedoman wawancara. Penelitii menerima informasi dari siswa secara langsung dengan menggunakan pedoman wawancara yang berisikan beberapa pertanyaan.

Adapun langkah-langkah analisis penelitian ini sebagai berikut:

1. Mengklasifikasikan skor 0 (sangat kurang), 1 (kurang), 2 (cukup), 3 (baik), 4 (sangat baik) yang diperoleh peneliti dari lembar observasi mengenai komunikasi dan kerjasama siswa.

2. Menghitung skor yang diperoleh dari lembar observasi dalam bentuk persentase dengan menggunakan rumus analisis deskriptif persentase yaitu sebagai berikut:

\section{Persentase $=$ Skor keseluruhan yang diperoleh $\times 100 \%$ \\ Skor maksimum}

Hasil perhitungan dalam bentuk persentase kemudian diinterpretasikan dengan tabel kriteria tingkat kemampuan komunikasi dan kerjasama siswa yaitu, $0-29 \%$ (sangat kurang baik) ; 30- $59 \%$ (kurang baik), 60 - $79 \%$ (cukup), $80-89 \%$ (baik) dan $90-100 \%$ (sangat baik).

\section{HASIL DAN PEMBAHASAN}

Penelitian ini dirancang untuk mendeskripsikan kemunculan komunikasi dan kerjasama siswa dalam permainan tradisional gapyak yang dilihat dari 2 aspek komunikasi menurut Depdiknas (Sari I. J, Murni D, Sjaifuddin, 2016) dan 4 aspek kerjasama menurut Isjoni (2010: 65-66). Hasil observasi peneliti, komunikasi dan kerjasama siswa yang sudah disebutkan di atas diringkas dalam sebuah tabel sebagai berikut. 
Table 1. Komunikasi Siswa

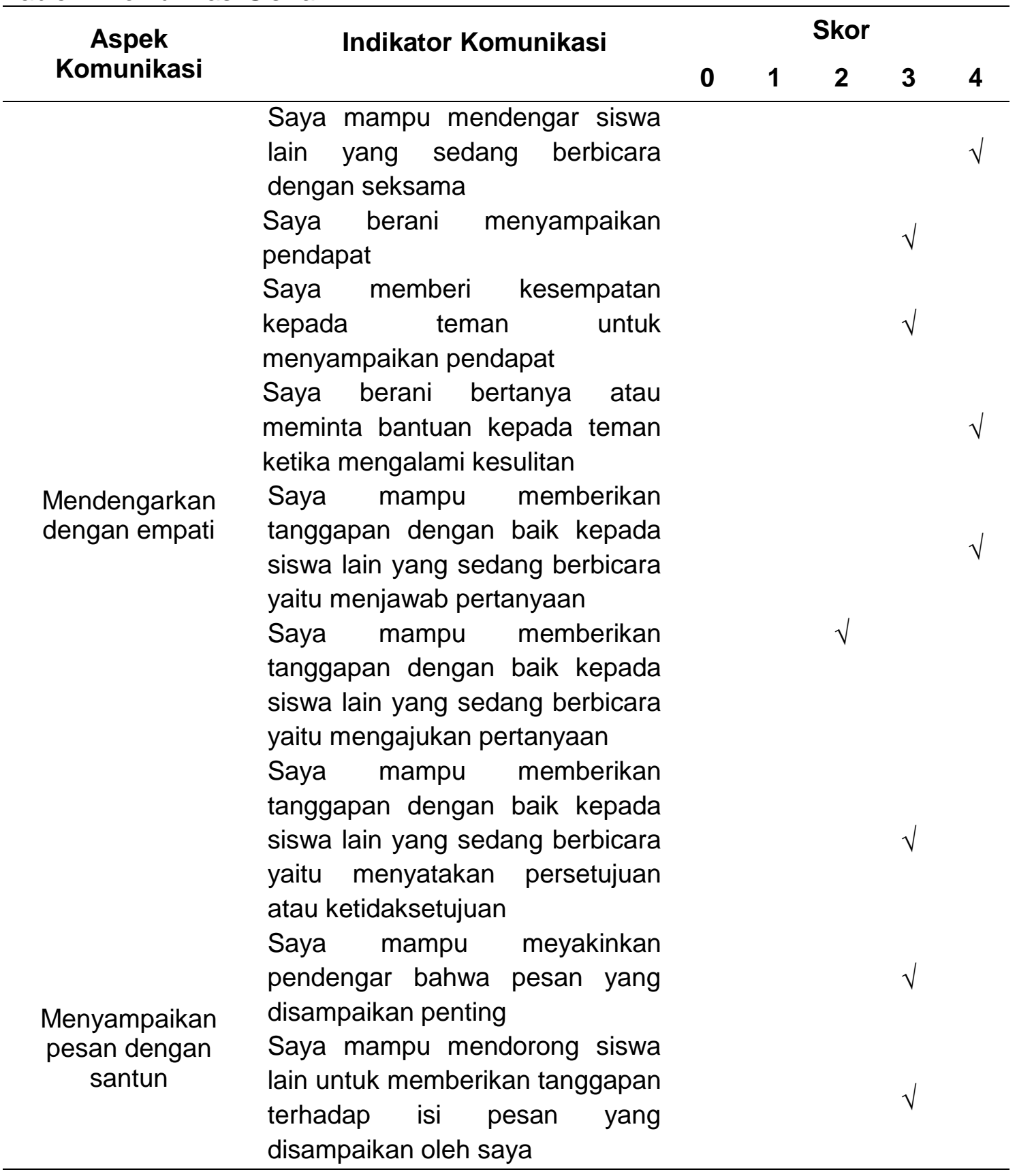

Berdasarkan hasil observasi pada tabel terhadap kemunculan komunikasi pada permainan tradisional gapyak, maka diperoleh data sebagai berikut:

1. Mendengarkan dengan empati

a. Saya mampu mendengar siswa lain yang sedang berbicara dengan seksama Siswa terlihat mendengarkan siswa lain yang sedang berbicara dengan seksama.

b. Saya berani menyampaikan pendapat Ada siswa yang berpendapat ketika mengatur strategi permainan.

c. Saya memberi kesempatan kepada teman untuk menyampaikan pendapat Ketika ada teman yang sedang berpendapat, teman lain mendengarkan.

d. Saya berani bertanya atau meminta bantuan kepada teman ketika mengalami kesulitan 
Ada siswa yang minta bantuan ketika terjadi ketidakseimbangan saat melakukan permainan gapyak.

e. Saya mampu memberikan tanggapan dengan baik kepada siswa lain yang sedang berbicara yaitu menjawab pertanyaan

Siswa menjawab pertanyaan dengan cepat ketika siswa lain bertanya.

f. Saya mampu memberikan tanggapan dengan baik kepada siswa lain yang sedang berbicara yaitu mengajukan pertanyaan

Ada siswa yang bertanya saat siswa lain menjelaskan

g. Saya mampu memberikan tanggapan dengan baik kepada siswa lain yang sedang berbicara yaitu menyatakan persetujuan atau ketidaksetujuan

Semua siswa berunding untuk menyatakan persetujuan atau ketidak setujuan dalam kelompok.

2. Menyampaikan pesan dengan santun

a. Saya mampu meyakinkan pendengar bahwa pesan yang disampaikan penting Ketika ketua kelompok menyampaikan pesan, semua anggota mendengarkan dengan seksama.

b. Saya mampu mendorong siswa lain untuk memberikan tanggapan terhadap isi pesan yang disampaikan oleh saya

Ketua kelompok memberikan kesempatan kepada anggotanya untuk menanggapi pesan yang disampaikan

Selanjutnya dihitung skor yang diperoleh dari lembar observasi dalam bentuk persentase dengan menggunakan rumus analisis deskriptif persentase yaitu sebagai berikut:

Persentase $=\frac{\text { Skorkeseluruhanyang diperoleh } \times 100 \%}{\text { Skormaksimum }}$

$$
\begin{aligned}
& =\frac{29}{36} \times 100 \% \\
& =80 \%
\end{aligned}
$$

Jadi, secara keseluruhan kemampuan komunikasi siswa dalam permainan tradisional gapyak berkriteria "baik" yaitu dengan persentase $80 \%$.

Aspek yang menjadi titik tekan dari peneliti dan paling mencolok untuk diamati dalam penerapan komunikasi di SD Negeri1 Bumirejo, yaitu (1) mendengarkan, (2) menyampaikan pesan. Berikut ini pembahasannya:

1. Mendengarkan dengan empati

Berdasarkan hasil observasi dan wawancara, siswa terlihat mendengarkan siswa lain yang sedang berbicara, mendengarkan pendapat siswa lain. Dengan demikian hasil observasi dan wawancara sesuai dengan indikator kemampuan siswa dalam mendengarkan dengan empati.

2. Menyampaikan pesan

Dari hasil observasi dan wawancara, siswa sudah mampu menyampaikan strategi dan memberikan semangat kepada teman sekelompoknya untuk memenangkan permainan. Dengan demikian hasil observasi dan wawancara sesuai dengan indikator kemampuan siswa dalam menyampaikan pesan. 
Tabel 2. Kerjasama Siswa

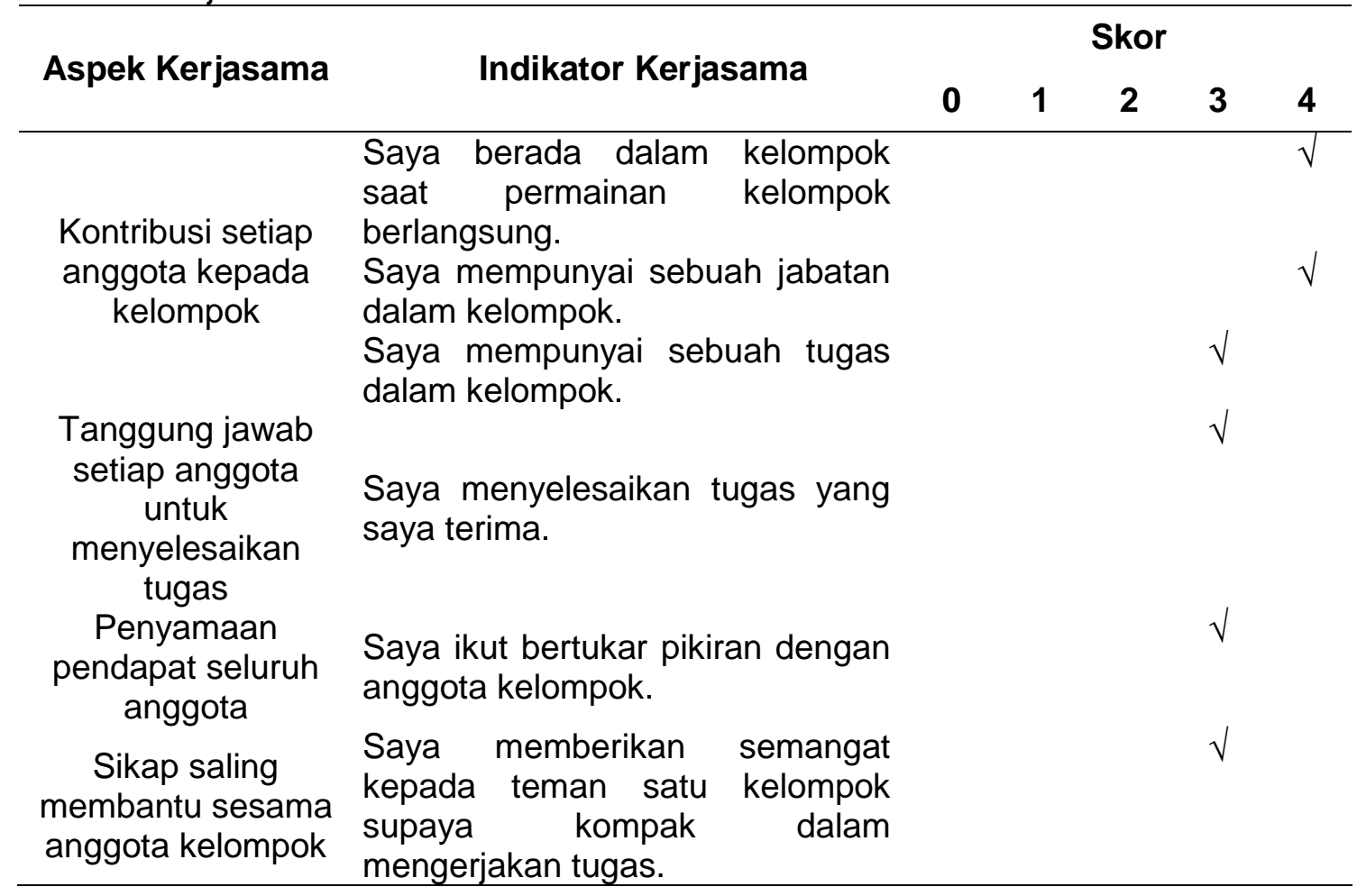

Berdasarkan hasil observasi terhadap kemunculan kerjasama pada permainan tradisional gapyak, maka diperoleh data sebagai berikut:

1. Kontribusi setiap anggota kepada kelompok

a. Saya berada dalam kelompok saat permainan kelompok berlangsung Siswa berada dalam kelompok selama permainan berlangsung.

b. Saya mempunyai sebuah jabatan dalam kelompok Dalam permainan ada ketua dan anggota.

c. Saya mempunyai sebuah tugas dalam kelompok Setiap jabatan memiliki tugasya masing-masing dalam kelompok.

2. Tanggung jawab setiap anggota untuk menyelesaikan tugas

a. Saya menyelesaikan tugas yang saya terima Siswa melaksanakan tugas dengan baik.

3. Penyamaan pendapat seluruh anggota

a. Saya ikut bertukar pikiran dengan anggota kelompok

Ketika sedang berdiskusi, ada anggota kelompok yang ikut berpartisipasi untuk berpendapat.

4. Sikap saling membantu sesama anggota kelompok

a. Saya memberikan semangat kepada teman satu kelompok supaya kompak dalam mengerjakan tugas

Semua anggota kelompok saling menyemangati dengan melakukan yel- yel sebelum permainan dimulai.

Selanjutnya dihitung skor yang diperoleh dari lembar observasi dalam bentuk persentase dengan menggunakan rumus analisis deskriptif persentase yaitu sebagai berikut:

Persentase $=\frac{\text { Skor keseluruhanyang diperoleh } \times 100 \%}{\text { Skor maksimum }}$ 


$$
\begin{aligned}
& =\frac{20}{24} \times 100 \% \\
& =83 \%
\end{aligned}
$$

Jadi, secara keseluruhan kemampuan kerjasama siswa dalam permainan tradisional gapyak berkriteria "baik" yaitu dengan persentase $83 \%$.

Aspek yang menjadi titik tekan dari peneliti dan paling mencolok untuk diamati dalam penerapan kerjasama di SD Negeri1 Bumirejo, yaitu (1) partisipasi (kontribusi) dalam kelompok, (2) interaksi tatap muka dengan kelompok, (3) menerima tanggung jawab, (4) melakukan musyawarah, serta (5) saling membantu sesama anggota kelompok. Berikut ini pembahasannya:

1. Partisipasi (kontribusi) dalam kelompok

Berdasarkan data hasil observasi dan wawancara, semua siswa sudah mampu mendorong partisipasi dalam kelompoknya. Hal tersebut ditunjukkan dengan sikap mereka yang tenang dan serius saat teman dalam kelompok menyampaikan pendapatny. Kepedulian mereka juga ditunjukkan dengan mengajak teman lain untuk ikut berpartisipasi apabila ada teman dalam kelompok itu yang kurang aktif atau yang hanya diam saja. Siswa yang terampil dalam kerjasama tidak hanya menyatakan komitmennya saja untuk mencapai tujuan kelompok, akan tetapi juga sanggup secara nyata memberikan perannya dengan mendorong partisipasi kepada teman lain untuk mencapai tujuan kelompok. Dengan demikian hasil observasi dan wawancara sesuai dengan indikator kemampuan partisipasi (kontribusi) setiap anggota kepada kelompok.

2. Menerima tanggung jawab

Berdasarkan data hasill observasi dan wawancara, maka ditemukan bahwa siswa sudah mampu menyampaikan ide secara jelas dan tidak ambigu misalnya siswa menggunakan kalimat yang jelas dan mudah dipahami. Dengan demikian hasil observasi dan wawancara sesuai dengan indikator kemampuan siswa dalam menerima tanggung jawab.

3. Melakukan musyawarah

Berdasarkan data hasil observasi dan wawancara, ditemukan bahwa siswa tidak hanya diam saja, namun sudah aktif memberikan ide pada kelompoknya walau masih malu-malu. Semua siswa sudah mulai percaya diri menyumbangkan idenya dalam kelompok dan tidak hanya mengikuti teman yang lain. Dengan demikian hasil observasi dan wawancara sesuai dengan indikator kemampuan melakukan musyawarah.

4. Saling membantu sesama anggota kelompok

Berdasarkan hasil observasi dan wawancara, maka ditemukan bahwa sebagian siswa sudah mampu mendengarkan pendapat teman lain dan tidak memaksakan pendapatnya, dan apabila menyampaikan pendapat yang salah, siswa mau memperbaikinya dan mau menerima masukan dari teman lain. Dengan demikian hasil observasi dan wawancara sesuai dengan indikator kemampuan saling membantu sesama anggota kelompok.

Melalui permainan tradisional dapat menumbuhkan siswa dalam mengembangkan kerjasama, membantu siswa menyesuaikan diri dengan lingkungan, saling berinteraksi secara positif, dapat mengkondisikan anak dalam mengntrol diri, mengembangkan sikap empati terhadap teman, menaati aturan, serta menghargai orang lain. Hal ini menunjukkan bahwa permainan tradisional dapat memberikan dampak yang sangat baik dalam membantu mengembangkan keterampilan emosi dan sosial anak. 


\section{SIMPULAN}

Berdasarkan hasil penelitian dan pembahasan, maka dapat disimpulkan bahwa kemampuan komunikasi dan kerjasama siswa pada permainan tradisional gapyak di SD Negeri 1 Bumirejo sudah mencapai dalam kriteria "baik" dilihat dari hasil persentase yaitu komunikasi $80 \%$ dan untuk kerjasama $83 \%$. Hasil ini diperoleh dari observasi yang menunjukkan siswa mampu mendengarkan dan menyampaikan pesan, berpartisipasi/berkontribusi dalam kelompok, berinteraksi tatap muka dengan kelompok, menerima tanggung jawab, melakukan musyawarah, serta saling membantu sesama anggota kelompok.

\section{DAFTAR PUSTAKA}

Adistyasari, R. (2013). "Meningkatkan Keterampilan Sosial dan Kerjasama Anak Dalam Bermain Angin Puyuh", Skripsi Universitas Negeri Semarang.

Sari I. J, Murni D, Sjaifuddin. (2016). Peningkatan Kecakapan Komunikasi Siswa Menggunakan Pembelajaran Biligual Preview Review dengan Setting Jigsaw pada Konsep Pengelolaan Lingkungan. Jurnal Penelitian dan pembelajaran IPA, 2 (2), 121-130.

Isjoni. (2012). Cooperative Learning. Bandung: Alfabeta. 